\title{
Recommended Plant Protecting Agents - Current Strategies in 22 Important Tobacco Exporting Countries*
}

\author{
by Wolfgang Wittekindt \\ Verband der Cigarettenindustrie, Hamburg
}

\section{SUMMARY}

A review is given of the present lists of crop protectants recommended for use on tobacco in the 22 countries which export the majority of tobacco to the Federal Republic of Germany.

The information is of significance in the overall monitoring and control of chemical residues on imported tobacco and in establishing priorities in developing methods of residue analysis for these chemicals.

\section{ZUSAMMENFASSUNG}

In einer Übersicht sind die Listen der Pflanzenschutzmittel zusammengefaßt, die gegenwärtig in 22 für den Tabakexport in die Bundesrepublik wichtigen Ländern für den Tabakanbau empfohlen werden.

Die Informationen zum Einsatz von Pflanzenbehandlungsmitteln haben Bedeutung für die Erfassung und Uberwachung chemischer Rückstände auf importierten Tabaken sowie für die Festlegung von Prioritāten für die Entwicklung von Rückstandsmethoden für diese Chemikalien.

\section{RESUME}

Les listes des produits recommandés actuellement pour. la protection des plantes dans 22 pays importants pour l'exportation de tabac vers l'Allemagne fédérale sont présentées de manière synoptique.

Les informations relatives aux produits utilisés pour traiter les plantes s'avèrent importantes pour la détection et le contrôle des résidus de produits chimiques contenus dans les tabacs importés, ainsi que pour l'établissement de priorités en vue de la mise au point de méthodes permettant d'analyser ces résidus.

\footnotetext{
" Received: 20th July 1985 - accepted: 29th August 1986.
}

\section{INTRODUCTION}

In common with many other crops in present day agriculture, tobacco crop protection is based on an integrated strategy. It involves certain agronomic practices, including crop rotation, attention to hygiene, the use of cultivars that are either resistant or, at least tolerant to harmful organisms, and the destruction of crop residues. It also demands extensive use of the knowledge available on the epidemiology of harmful organisms, of predators, and ecological consequences of control and of economic thresholds of damage. Careful observation of the crop at all stages of its growth, requiring a high degree of theoretical knowledge and practical experience by the producer, and scouting to monitor the degree of infestation are also integral parts of this strategy. Finally, it requires the judicious use of approved crop chemicals which should be applied only when absolutely essential.

This paper reviews the changing situation in the world, of crop chemicals approved for the use on tobacco. It results from discussions with tobacco research personnel (1) and the representatives of manufacturers of plant protecting agents and recent compilations of recommended formulations in the important tobacco cultivating countries. This review would appear to be appropriate in view of the fact that eight years have elapsed since the West German decree regarding chemical residues.

In 1978, eleven tolerances for residues were fixed (see Table 1), as cited in appendix 2 of the decree of 13 th June 1978 on the maximum permissible amounts of plant protecting agents (appendix 4 of the amendment of 24th June, 1982, unchanged by the amendment of 18th April, 1984). The text of article 3 (paragraph 2) of the decree of 13th June, 1978 and of article 6 (paragraph 2) of the amendment of 24th June, 1982 also contain a fundamental statement regarding all other plant protectants used in tobacco cultivation: "Tobacco 
Table 1.

Permissible maximum residue amounts in or on tobacco products, which are Intended for sale to the consumer.

\begin{tabular}{|c|c|c|}
\hline \multicolumn{2}{|c|}{ Substance } & $\begin{array}{c}\text { Maximum } \\
\text { permitted } \\
\text { amounts } \\
\text { in tobacco } \\
(\mathrm{mg} / \mathrm{kg})\end{array}$ \\
\hline $\begin{array}{l}\text { aldicarb } \\
\text { aldicarb-sulphoxide } \\
\text { aldicarb-sulphone }\end{array}$ & $\begin{array}{l}\text { calculated in total as } \\
\text { aldicarb }\end{array}$ & 10.0 \\
\hline $\begin{array}{l}\text { aldrin } \\
\text { dieldrin }\end{array}$ & \multirow[t]{2}{*}{$\begin{array}{l}\text { calculated in total as } \\
\text { dieldrin }\end{array}$} & 0.3 \\
\hline chlordane & & 0.2 \\
\hline $\begin{array}{l}\text { DDT and its isomers } \\
\text { DDD and its isomers } \\
\text { DDE and its isomers }\end{array}$ & \multirow[t]{3}{*}{$\begin{array}{l}\text { calculated in total as } \\
\text { DDT }\end{array}$} & 10.0 \\
\hline dimefox & & 0.01 \\
\hline endrin & & 0.3 \\
\hline $\begin{array}{l}\text { heptachlor } \\
\text { heptachlor epoxide }\end{array}$ & \multirow[t]{2}{*}{$\begin{array}{l}\text { calculated in total as } \\
\text { heptachlor }\end{array}$} & 0.2 \\
\hline hexachlorbenzene & & 0.3 \\
\hline \multicolumn{2}{|c|}{ BHC isomers excl. lindane } & 1.0 \\
\hline $\begin{array}{l}\text { phosphorus hydrides } \\
\text { phosphine }\end{array}$ & $\begin{array}{l}\text { calculated in total as } \\
\text { phosphorus hydrides }\end{array}$ & 0.01 \\
\hline \multicolumn{2}{|c|}{ camphechlor (toxaphene) } & 5.0 \\
\hline
\end{tabular}

Table 2.

Plant protection and growth regulation agents, the use of which is allowed if the rules of good agricultural practice are observed so that the residue levels in the final products cannot exceed the recommended maximum amounts.

\begin{tabular}{l|c}
\hline Plant treatment substances & $\begin{array}{c}\text { Recommended } \\
\text { maximum amounts } \\
(\mathrm{mg} / \mathrm{kg})\end{array}$ \\
\hline
\end{tabular}

1a. Insecticides

(with an organochlorine basis)

endosulfan

20.0

lindane (gamma-BHC)

2.0

methoxychlor

1b. Insecticides

(with an organophosphorus basis)

azinphosmethyl, also effective as acaricide

1.0

azinphosethyl, also effective as acaricide

1.0

bromophos, also effective as acaricide

1.0

chlorfenvinphos [Birlane]

1.0

demeton-S-methyl [Metasystox 1]

1.0

diazinon [Basudin], also effective as acaricide

1.0

dichlorvos, also effective as

stock protection agent

1.0

dimethoate

1.0

disulfoton, also effective as

acaricide and nematicide

1.0

ethoprop [Mocap], also effective as nematicide
Table 2 (cont'd.)

Insectlcides (with an organophosphorus basis) (cont'd)

fenamiphos [Nemacur], also effective as nematicide

15.0

fenchlorphos, also effective as acaricide $\quad 1.0$

fenitrothion

1.0

fensulfothion [Terracur P], also effective as nematicide

2.0

fenthion [Lebaycid]

1.0

fonofos [Dyfonate]

1.0

formothion [Anthio], also effective as acaricide

1.0

malathion

3.0

methidathion, also effective as acaricide

1.0

mevinphos, also effective as acaricide $\quad 1.0$

monocrotophos [Azodrin] 1.0

naled [Dibrom] $\quad 1.0$

parathion, also effective as acaricide $\quad 1.0$

parathion-methyl, also effective as acaricide $\quad 1.0$

phorate [Thimet] 1.0

phosalone, also effective as acaricide $\quad 2.0$

phosphamidon, also effective as acaricide $\quad 1.0$

salithion 1.0

tetrachlorvinphos $\quad 2.0$

thionazine, also effective as nematicide $\quad 1.0$

trichlorfon [Dipterex] $\quad 1.0$

vamidothion, also effective as acaricide $\quad 1.0$

1c. Insecticides

(with a carbamate basis)

aminocarb [Matacil], also effective as

acaricide

1.0

carbaryl [Sevin]

3.0

carbofuran [Furadan], also effective as

nematicide

20.0

methomyl [Lannate], also effective as

nematicide

2.0

propoxur, also effective as acaricide

2. Funglcides

anilazine

1.0

benomyl

carbendazim

calculated in total as

carbendazim

5.0

captan

5.0

chinomethionate [Morestan]

0.3

copper compounds, also effective as

acaricides

30.0

dichloran

0.1

dinocap, also effective as acaricide $\quad 1.5$

folpet

5.0

dithiocarbamates (DTC):

$\begin{aligned} & \text { ferbam } \\ & \text { mancozeb } \\ & \text { maneb } \\ & \text { metiram } \\ & \text { methylmetiram } \\ & \text { nabam } \\ & \text { propineb [Antracol] } \\ & \text { thiram } \\ & \text { zineb } \\ & \text { ziram }\end{aligned} \quad$ in total estimated
as $\mathrm{CS}_{2}$

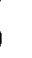

0

.

0

0

0

0

0

0




\section{Nematicides}

carbofuran [Furadan], also effective as insecticide

ethoprop [Mocap], also effective as

insecticide

fenamiphos [Nemacur]

fensulfothion [Terracur], also effective as insecticide

ethylene dibromide [Dorlone]

methomyl [Lannate], also effective as insecticide

thionazin, also effective as insecticide

\section{Herbicides}

alachlor

isopropalin [Paarlan]

pebulate

napropamide [Devrinol]

diphenamid [Enide]

linuron calculated as 3,4-dichloraniline

metobromuron [Patoran] calculated as

4-bromoaniline

metoxuron calculated as

3-chloro-4-metoxyaniline

monolinuron calculated as

monuron 4-chloraniline

\section{Stock protectants}

hydrocyanic acid (HCN)

dichlorvos (DDVP), also effective as insecticide

phoxim

piperonyl butoxide

pyrethrins

\section{Sucker control agents}

maleic hydrazide $(\mathrm{MH})$

products may also be commercially marketed if and when residues of non-registered pesticides are found on or in tobacco products for which, according to paragraph 1, no maximum permissible quantities are laid down, provided that the existent quantity of the said pesticides is not harmful to human health". This supplement by the West German legislating authorities was commented on in 1978 by representatives of the cigarette industry.

Since then, the cigarette industry and the manufacturers of plant protecting agents, in co-operation with the West German Federal Health Office in Berlin (Bundesgesundheitsamt), have agreed on recommended maximum amounts of residues (2). In the 1978 paper the list of recommended maximum residue amounts was made available as a guideline, to associates in tobacco producing countries (see Table 2). It is possible to judge the strategies pursued by the important producing countries during the intervening period by comparing the lists of chemicals used then and now. Many criteria are involved in decisions regarding the strategies for the approval of plant protecting agents.

In accordance with statements issued by the North Carolina Agricultural Extension Service (3), the following points should be considered:

- Which plant diseases and harmful organisms need to be controlled?

- Which products are the most effective on different kinds of organisms destructive to tobacco?

- What residue problems can be caused by the use of the recommended agents? (It is then, for example, necessary to find a substitute.)

- Are these products available?

- Are the necessary equipment and labour available (e.g. for spraying)?

- What hazards to the operator and other workers have to be taken into account?

- Does the label of each container hold full instructions on how to apply the various remedies? (It is imperative that these instructions be read carefully and applied correctly to safeguard the environment.)

- Can resistance be induced by these products?

Another factor is the decisive role the lobby of manufacturers of plant protecting agents plays in various countries. (For example, such manufacturers can have been supplying plant protecting agents for use on other crops to these same countries for some time.)

The manufacturers of tobacco products who purchase leaf tobacco on a world-wide basis cannot remain indifferent towards the strategies concerning recommendation and use of plant protecting agents in the important tobacco growing countries. To clarify this, the author would like to emphasize the following:

- If the most important tobacco growing countries select a few insecticides, fungicides, nematicides, herbicides or stock protecting and growth regulating agents from the total spectrum of all formulations, a proliferation of residues occurs.

- Limitation to relatively few chemicals common to many cultivating countries can facilitate routine residue monitoring of specific plant protecting agents, as the leaf then has to be screened for fewer substances.

- If one of these agents is suddenly found to be undesirable, e.g. on the basis of new toxicological findings, then the lowering of the maximum permissible residue level or even a recommendation to cease using such agent and to enforce this in practice, requires much more effort compared with such instances where agents are used in only a few countries. 
- Proposals have been presented to vary the use of specific substances for plant treatment (insecticides, fungicides, growth regulators) within the bounds of possibilities (4). It is important to know how extensively these agents are being used.

- To be able to make a decision regarding the priorities resulting from the development of residue methods since 1978 (5), it would appear essential to record the chemical structures of the newly introduced agents and the extent of their use.

- As it is possible for plant protecting agents to become resistant, it is worthwhile knowing which types of agents are being used to an increasing extent and which are on the way out.

In the present compilation, the lists made in 1978 (2) are compared with the latest information. We have tried to find the answers to the following questions:

1. Which formulations are currently being recommended by the important cultivating countries?

2. Are the same formulations being proposed in various countries?

3. What new products have been introduced since 1978 and in which countries?

4. What other special features ascertained are involved in the strategy of application (e.g. 2pplication of composite formulations or combined application of several preparations against different harmful organisms).

In general, many more plant protecting agents are recommended in the countries surveyed than are actually being used, because in different regions, various products are available to control different harmful organisms or combinations of different organisms. This is necessary in case a distinct resistance develops and further products with similar effect but different chemical mechanism have to be made available. A greater variety of formulations also means there is a better. chance of finding an effective substitute. The lists refer to those chemicals which have been approved by the respective countries. In each country they may be used in particular areas and at specific stages of crop life only (6).

\section{ME'THODOLOGY}

The recommended substances had been compiled in the 1978 publication, following the categories differentiated by the experts at the Federal Health Office in Berlin.

\section{Categories to be considered:}

1. Substances for which tolerances were fixed for tobacco products in the decree of 13th June, 1978 on maximum permissible amounts of plant protecting agents.

2. Substances for which recommended maximum residue amounts for tobacco products were fixed in agreement with the Federal Health Office.

3. Substances for which tolerances were fixed for vegetable foodstuffs in the above-mentioned decree and its amendments.

4. Substances that have been registered only for vegetable foodstuffs in the Federal Republic.

5. Substances not registered in the Federal Republic (mainly chemicals unnecessary for West German agriculture).

As far as the newly introduced plant protecting agents are concerned, several manufacturers of crop chemicals have either requested that recommended maximum amounts in tobacco products be fixed or have at least expressed an interest in it being done. Manufacturers of tobacco products prefer using substances with recommended maximum amounts.

In respect of the nomenclature of the plant protecting agents mentioned in this publication, a well-known trade name has frequently been cited in square brackets (7), in addition to the common name.

For the purpose of the evaluation, information has been surveyed about recommended pesticides (plant protectants) in 22 countries; 17 of these belong to the 20 most important countries which export tobacco to the Federal Republic of Germany: U.S.A. (US), Italy (I'T), South Korea (KO), Brazil (BR), Mexico (ME), Greece (GR), Turkey (TR), Thailand (TH), Zimbabwe (ZI), Canada (CA), Philippines (PH), Argentina (AR), Bulgaria (BU), Indonesia (ID), France (FR), Yugoslavia (YU), Colombia (CO), Tanzania (TN), Dominican Republic (DR), India (IN), Zambia (ZA), South Africa (SA).

The sequence in which the countries appear is based on their relative importance to West German tobacco imports; the names of the countries have been abbreviated in brackets.

\section{RESULTS OF A REVIEW OF THE PRESENT LISTS OF RECOMMENDED CROP CHEMICALS}

\section{Insecticides}

In general, the number of recommended products for insect control seems to be disproportionally high compared with the number of agents recommended for control of nematodes, fungi, weeds and those for stock protection and growth regulation. However, of the 51 products listed as insecticides, 21 are multi-purpose agents, 13 are also acaricides, 8 nematicides, 2 herbicides, and 1 is also a stock protecting agent. This means 
that considerably fewer than all those agents listed in this category are actually used to deal with infestation.

One interesting question from the list published in 1978 is: "Which insecticides are still recommended in different regions of world tobacco cultivation, e.g. North, Central and South America, Southern Europe, South Africa, and Eastern Asia?"

To avoid repetition, insecticides with dual action are listed under the headings "nematicides" and "herbicides", but the extent to which they are recommended is shown in the section "insecticides".

The result of the comparison reads: The following agent with a tobacco tolerance is being recommended in different parts of the world:

aldicarb [Temik] in 8 countries (US, BR, ME, GR, TH, YU, DR, SA).

Of the group of ORGANOCHLORINE BASED INSECTICIDES, three with recommended maximum residue amounts set in 1978 , are recommended:

endosulfan in 14 countries (US, BR, ME, GR, TR, TH, PH, AR, ID, FR, TN, DR, IN, SA),

lindane in 3 countries (US, CA, YU),

methoxychlor in 1 country (US).

The ORGANOPHOSPHORUS BASED CHEMICALS had been developed to replace the organochlorine based ones. Previously, 32 organophosphorus based chemicals were listed, for which recommended maximum residue amounts had been stipulated (2). Of these, 22 are still being recommended in the countries listed in Table 3.

In addition to the organophosphorus based insecticides, CARBamate BASED PLANT PROTECTING AGENTS were listed in 1978 as another formulation to replace the organochlorine ones. This list includes five agents. It is interesting to note that of this group:

methomyl [Lannate] is currently recommended in 15 countries (US, IT, ME, GR, TR, TH, ZI, CA, PH, AR, ID, FR, YU, CO, SA),

carbaryl [Sevin] in 11 countries (US, IT, BR, ME, CA, PH, AR, FR, DR, IN, SA),

carbofuran [Furadan] in 11 countries (US, BR, GR, TH, AR, BU, ID, YU, TN, DR, SA),

propoxur in 1 country (CA).

As there are no recommendations for aminocarb [Matacil], it would appear to have been withdrawn from the market.

Whereas the above-mentioned substances were registered in 1978 with recommended maximum residue amounts - in agreement with the West German Federal Health Office - three additional agents were cited in the 1978 publication. No information was received about the use of carbophenothion and menazon, but
Table 3.

Organophosphorus based Insecticldes with recommended maximum amounts for tobacco.

\begin{tabular}{|c|c|}
\hline Insecticides & recommended in \\
\hline monocrotophos [Azodrin] & $\begin{array}{l}11 \text { countries } \\
\text { (US, BR, ME, TH, ZI, AR, } \\
\text { ID, CO, DA, IN, SA) }\end{array}$ \\
\hline dimethoate & $\begin{array}{l}10 \text { countries } \\
\text { (US, TR, TH, ZI, AR, FR, } \\
\text { YU, TN, ZA, SA) }\end{array}$ \\
\hline malathion & $\begin{array}{l}7 \text { countries } \\
\text { (US, ME, TR, CA, FR, } \\
\text { DR, SA) }\end{array}$ \\
\hline trichlorfon [Dipterex] & $\begin{array}{l}6 \text { countries } \\
\text { (US, ME, TR, CA, ID, DR) }\end{array}$ \\
\hline diazinon [Basudin] & $\begin{array}{l}6 \text { countries } \\
\text { (US, BR, TR, CA, ID, DR) }\end{array}$ \\
\hline parathion-methyl & $\begin{array}{l}5 \text { countries } \\
\text { (US, GR, TR, FR, DR) }\end{array}$ \\
\hline phosphamidon [Dimecron] & $\begin{array}{l}5 \text { countries } \\
\text { (ME, FR, TN, IN, SA) }\end{array}$ \\
\hline demeton-S-methyl [Metasystox I] & $\begin{array}{l}4 \text { countries } \\
\text { (ZI, DR, IN, SA) }\end{array}$ \\
\hline dichlorvos (DDVP) * & $\begin{array}{l}4 \text { countries } \\
\text { (US, GR, TR, DR) }\end{array}$ \\
\hline ethoprop [Mocap] & $\begin{array}{l}4 \text { countries } \\
\text { (US, IT, GR, DR) }\end{array}$ \\
\hline fenamiphos [Nemacur] & $\begin{array}{l}4 \text { countries } \\
\text { (US, GR, DR, SA) }\end{array}$ \\
\hline fenthion [Lebaycid] & $\begin{array}{l}4 \text { countries } \\
\text { (BR, TR, ID, DR) }\end{array}$ \\
\hline disulfoton [Disyston] & $\begin{array}{l}3 \text { countries } \\
\text { (US, AR, ZI) }\end{array}$ \\
\hline formothion [Anthio] & $\begin{array}{l}3 \text { countries } \\
\text { (TR, TH, AR) }\end{array}$ \\
\hline parathion & $\begin{array}{l}3 \text { countries } \\
\text { (US, IT, TR) }\end{array}$ \\
\hline azinphosmethyl & $\begin{array}{l}2 \text { countries } \\
\text { (US, CA) }\end{array}$ \\
\hline fensulfothion [Terracur P] & $\begin{array}{l}2 \text { countries } \\
\text { (US, DR) }\end{array}$ \\
\hline methidathion & $\begin{array}{l}2 \text { countries } \\
\text { (US, ME) }\end{array}$ \\
\hline mevinphos & $\begin{array}{l}2 \text { countries } \\
\text { (CA, SA) }\end{array}$ \\
\hline naled & $\begin{array}{l}2 \text { countries } \\
\text { (US, DR) }\end{array}$ \\
\hline tetrachlorvinphos & $\begin{array}{l}2 \text { countries } \\
\text { (IT, SA) }\end{array}$ \\
\hline fonofos [Dyfonate] & $\begin{array}{l}1 \text { country } \\
\text { (US) }\end{array}$ \\
\hline
\end{tabular}

* Mainly used as stock protectant. chlorpyrifos [Dursban] is recommended in 10 countries (US, IT, FR, TR, ZI, CA, AR, FR, ZA, SA). 
Table 4.

Insecticides already recommended in 1978.

\begin{tabular}{l|l}
\hline Insecticides & recommended in \\
\hline acephate [Orthene] & 17 countries \\
& (US, IT, KO, BR, ME, GR, \\
& TR, TH, Zl, CA, PH, AR, \\
& ID, FR, IN, ZA, SA) \\
& 8 countries \\
methamidophos [Monitor, Tamaron] & (ME, GR, TR, TH, PH, FR, \\
& YU, TN) \\
pirimicarb & 5 countries \\
& (GR, TR, CA, BU, FA) \\
methyl isothiocyanate [Trapex] & 4 countries \\
& (US, GR, TR, CA) \\
dichloropropene & 3 countries \\
& (US, Zl, CA) \\
ethiofencarb [Crotenon] & 2 countries \\
thiometon [Ekatin] & (TR, BU) \\
& 2 countries \\
oxamyl [Vydate] & (TR, IN) \\
mercaptodimethur (methiocarb) & 2 countries \\
& (US, GR) \\
& (US) \\
\hline
\end{tabular}

The new information for agents mentioned in the 1978 publication (2) is shown in Table 4.

It should be pointed out that none of the six agents coumaphos, ESP, leptophos, phenthoate, phosphalon [Cyolane] and temephos, which were previously mentioned, is recommended any longer in the tobacco cultivating countries surveyed.

New Insecticides: The result of the inquiries about new chemical compounds and formulations used as insecti-

Table 5. Pyrethrold insectlcides introduced later than 1978.

\begin{tabular}{ll}
\hline Insecticides & recommended in \\
\hline permethrin [Ambush] & $\begin{array}{l}8 \text { countries } \\
\text { (IT, BR, TR, Zl, CA, PH, } \\
\text { AR, SA) }\end{array}$ \\
& 6 countries \\
deltamethrin [Decis] & (IT, BR, ZI, CA, BU, FR) \\
& 5 countries \\
cypermethrin [Ripcord] & $(\mathrm{ZI}, \mathrm{CA}, \mathrm{PH}, \mathrm{FR}, \mathrm{ZA})$ \\
allethrin (allyl cinerin) & 2 countries \\
fenvalerate [Pydrin] & (US, IT). \\
& 1 country \\
& (ME) \\
\hline
\end{tabular}

cides since 1978 is as follows: The electronic data processing (EDP) classification system designates the group of organochlorine compounds as "1st genera-

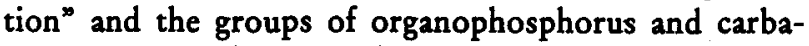
mate compounds as “2nd generation". Meanwhile the PYRETHROID COMPOUNDS have entered the scene as ${ }^{*}$ 3rd generation" insecticides, which have already been differentiated into formulations of the "1st wave" (natural pyrethrins) and the "2nd wave" (synthetic pyrethroids). Recent attention has been directed towards the ${ }^{\alpha} 2$ nd wave" of pyrethroids, with the intention of achieving even more selectivity with these formulations, that is, for example, harmlessness towards fish or bees.

For better understanding it should be pointed out that

- the pyrethrins are chemically very unstable,

- the "1st wave" of pyrethroids has resulted in products, which although they are chemically stable, do not currently have any systemic effect,

- in the "2nd wave" of pyrethroids, attempts are being made to develop formulations which have a systemic effect (translaminar) and work via the vapour phase (8).

Since 1978, the pyrethroids shown in Table 5 have been recommended in tobacco cultivating countries.

Recent inquiries have shown that, since 1978, a further six insecticides have been recommended, each in one country:

carbon tetrachloride (US),

demephion [Tinox] (GR),

fentin hydroxide (US),

oxydemeton-methyl [Metasystox R] (CA),

pirimiphos-methyl [Actellic] (TN),

rotenone [Derris] (US).

In addition there are several COMPOSITE FORMULATIONS (insecticide + herbicide), recommended especially in Canada:

acephate [Orthene] + napropamide [Devrinol],

cypermethrin [Ripcord] + napropamide,

permethrin [Ambush] + napropamide.

This is also the case in the U.S.A. In Zimbabwe, dimethoate plus a suckercide and an insecticide plus a herbicide (Dual), are recommended in appropriate situations.

\section{Fungicides}

The change in the use of fungicides has turned out to be similar to that of insecticides. Thus, it has been of great interest to determine which fungicides from the 1978 list are still being recommended. The result of this comparison reads: The group of fungicides with recom- 
Table 6.

Fungleides with recommended maximum residue amounts for tobacco, flxed up to 1978.

\begin{tabular}{|c|c|}
\hline Fungicides & recommended in \\
\hline zineb & $\begin{array}{l}11 \text { countries } \\
\text { (US, IT, KO, BR, GR, TR, } \\
\text { AR, BU, YU, DR, SA) }\end{array}$ \\
\hline mancozeb & $\begin{array}{l}10 \text { countries } \\
\text { (US, IT, KO, ME, TR, ZI, } \\
\text { CA, AR, ID, SA) }\end{array}$ \\
\hline maneb & $\begin{array}{l}9 \text { countries } \\
\text { (US, ME, GR, TR, AR, ID, } \\
\text { FR, DR, ZA) }\end{array}$ \\
\hline benomyl & $\begin{array}{l}7 \text { countries } \\
\text { (ZI, CA, BU, FR, DR, } \\
\text { ZA, SA) }\end{array}$ \\
\hline copper compounds & $\begin{array}{l}7 \text { countries } \\
\text { (US, AR, BU, ID, YU, } \\
\text { DA, SA) }\end{array}$ \\
\hline dinocap & $\begin{array}{l}7 \text { countries } \\
\text { (GR, ZI, BU, FR, YU, } \\
\text { DA, SA) }\end{array}$ \\
\hline captan & $\begin{array}{l}5 \text { countries } \\
\text { (US, CA, AR, DR, SA) }\end{array}$ \\
\hline propineb [Antracol] & $\begin{array}{l}5 \text { countries } \\
\text { (IT, BR, GR, TR, YU) }\end{array}$ \\
\hline thiram & $\begin{array}{l}5 \text { countries } \\
\text { (US, TR, ZI, DR, ZA) }\end{array}$ \\
\hline anilazine & $\begin{array}{l}2 \text { countries } \\
\text { (US, ZI) }\end{array}$ \\
\hline dichloran & $\begin{array}{l}2 \text { countries } \\
\text { (ZI, DR) }\end{array}$ \\
\hline ferbam & $\begin{array}{l}2 \text { countries } \\
\text { (US, AR) }\end{array}$ \\
\hline metiram & $\begin{array}{l}2 \text { countries } \\
\text { (US, AR) }\end{array}$ \\
\hline
\end{tabular}

Captafol would appear to be no longer in use.

mended maximum residue amounts for tobacco consisted of 19 substances in 1978. For the recent recommendations see Table 6.

The following four fungicides are still being recommended:

dazomet [Basamid] in 7 countries (US, BR, GR, CA, TN, IN, SA),

methyl isothiocyanate in 4 countries (US, GR, TR, CA),

dichloropropene [Telone] in 3 countries (US, ZI, CA), thiabendazole in 2 countries (US, BR).

New Fungicides: In the case of fungicides, an important change has also taken place since 1978, subsequent to the development of metalaxyl [Ridomil], a very effec-
Table 7.

Funglcides introduced later than 1978.

\begin{tabular}{ll}
\hline Fungicides & recommended in \\
\hline metalaxyl [Ridomil] & 10 countries \\
& (US, IT, GR, CA, AR, BU, \\
& FR, YU, DR, SA) \\
metham-sodium [Vapam] & 3 countries \\
& (US, GR, CA) \\
benodanil [Calirus] & 1 country \\
& (ZI) \\
carbon tetrachloride & 1 country \\
& (US) \\
fenaminosulf [Diazoben] & 1 country \\
fentin hydroxide & (BR) \\
furalaxyl [Fongarid] & 1 country \\
& (US) \\
thiophanate [Topsin] & 1 country \\
triadimefon [Bayleton] & (IT) \\
& 1 country \\
& (BU) \\
& 1 country \\
& (YU) \\
& 1 country \\
& (US) \\
\hline
\end{tabular}

" On a trial basis only.

tive agent to combat Peronospora tabacina (blue mould) and Phytophthora parasitica (black shank). (Because several cases of resistance to this agent have been recorded, the manufacturer now offers a composite formulation consisting of mancozeb and Ridomil (Ridomil MZ).) Table 7 shows the newly introduced fungicides.

\section{Nematicides}

Those agents listed in 1978 to combat nematodes are also compared with today's recommendations for insecticides and fungicides in the same way.

In 1978, the group of nematicides with recommended maximum residue amounts for tobacco consisted of seven agents. Of these, the following five are still being recommended:

methomyl [Lannate] in 15 countries, carbofuran [Furadan] in 11 countries, ethoprop [Mocap] in 4 countries, fenamiphos [Nemacur] in 4 countries, fensulfothion [Terracur P] in 2 countries.

For detailed information about the different countries, compare the corresponding paragraph of the section "insecticides". Ethylene dibromide [EDB] is still recommended (ZI, TN, ZA), but thionazin is no longer 
recommended in the countries surveyed. Dibromchloropropane [Nemagon] appears to have been withdrawn.

A further group of nematicides consisted of only seven agents. For detailed information about the different countries with regard to five of the nematicides, compare the corresponding paragraphs of the section on either "insecticides" [I] or "fungicides" [F]:

dazomet is recommended in 7 countries [F], methyl isothiocyanate [Trapex] in 4 countries [I], dichloropropene [Telone] in 3 countries [I], oxamyl [Vydate] in 2 countries [I],

thiabendazole in 2 countries [F].

Effective as nematicides only are:

D-D [Nemex], recommended in 5 countries (US, IT, CA, GR, SA),

chloropicrin in 2 countries (US, SA).

Coumaphos no longer seems to be used.

New Nematicides: New nematicides which have been recommended since 1978 are:

metham-sodium [Vapam] (also effective as fungicide) in 3 countries (US, GR, CA),

Bunema in 1 country (US),

diamidafos [Nellite] in 1 country (US).

\section{Herbicides}

Agents used in 1978 on weeds compare with today's world-wide recommendation as follows: The herbicides with recommended maximum amounts for tobacco consisted in 1978 of ten agents, of which five are still being recommended (see Table 8).

Table 8.

Herblcides with recommended maximum amounts for tobacco, fixed up to 1978.

\begin{tabular}{l|l}
\hline Herbicides & recommended in \\
\hline diphenamid [Enide] & 9 countries \\
& (US, IT, BR, GR, ZI, CA, \\
& BU, DR, SA) \\
isopropalin [Paarlan] & 5 countries \\
& (US, IT, GR, DR, SA) \\
napropamide [Devrinol] & 5 countries \\
pebulate [Tillam] & (US, GR, ZI, CA, BU) \\
& 5 countries \\
metobromuron [Patoran] & (US, GR, ZI, CA, SA) \\
& 3 countries \\
& (ZI, FR, DR) \\
\hline
\end{tabular}

Alachlor, linuron, metoxuron and monolinuron appear to be no longer in demand.
The following two herbicides already mentioned in 1978, are still being used for tobacco:

benfluralin [Benefin] is recommended in 3 countries (US, IT, YU),

trifluralin [Treflan] in 3 countries (IT, ZI, AR).

From another group of 5 herbicides already mentioned in 1978,

dazomet [Basamid] is recommended in 7 countries [F], methyl isothiocyanate in 4 countries [I],

dichloropropene [Telone] in 3 countries [I].

For detailed information on the recommendations of the above-listed agents, see the corresponding paragraphs of the sections on either "insecticides" [I] or "fungicides" [F].

Nitralin [Planavin] is used in 1 country (ZI) and nitrofen would appear to be no longer used or available.

The herbicides dichlormate [Sirmate], siduron, and vernolate are, according to the author's information, no longer used.

New Herbicides: New herbicides recommended since 1978 are shown in Table 9.

Table 9.

Herbicides introduced later than 1978.

\begin{tabular}{|c|c|}
\hline Herbicides & recommended in \\
\hline pendimethalin [Accotab, Prowl] * & $\begin{array}{l}7 \text { countries } \\
\text { (US, IT, BR, GR, ZI, AR, SA) }\end{array}$ \\
\hline oryzalin [Surflan] & $\begin{array}{l}3 \text { countries } \\
\text { (US, ZI, SA) }\end{array}$ \\
\hline perfluidone [Destun] & $\begin{array}{l}2 \text { countries } \\
\text { (US, SA) }\end{array}$ \\
\hline butam & $\begin{array}{l}2 \text { countries } \\
(\mathrm{GR}, \mathrm{ZI})\end{array}$ \\
\hline alloxydim-sodium & $\begin{array}{l}1 \text { country } \\
\text { (FR) }\end{array}$ \\
\hline Bi-Span & $\begin{array}{l}1 \text { country } \\
\text { (SA) }\end{array}$ \\
\hline chlorpropham (cloro IPC) & $\begin{array}{l}1 \text { country } \\
\text { (US) }\end{array}$ \\
\hline ethofumesate [Tramat] & $\begin{array}{l}1 \text { country } \\
\text { (FR) }\end{array}$ \\
\hline flamprop-methyl [Mataven] & $\begin{array}{l}1 \text { country } \\
\text { (TH) }\end{array}$ \\
\hline fluazifop-butyl [Fusilade] & $\begin{array}{l}1 \text { country } \\
(\mathrm{ZI})\end{array}$ \\
\hline metolachlor [Dual] & $\begin{array}{l}1 \text { country } \\
(\mathrm{ZI})\end{array}$ \\
\hline
\end{tabular}

" With a recommended maximum amount for tobacco products. 


\section{Stock Protecting Agents}

Chemicals, mentioned in 1978, used on stored tobacco compare with today's recommendations in the countries surveyed as follows: In 1978, recommended maximum amounts for tobacco bad been fixed for five agents, four of these are still being recommended today:

dichlorvos (DDVP) in 10 countries (US, IT, ME, GR, TR, CA, BU, YU, TN, DR), phoxim [Baythion] in 2 countries (KO, DR), piperonyl butoxide in 2 countries (IT, SA), pyrethrins in 2 countries (US, SA).

Hydrocyanic acid (HCN) would appear to be no longer in use. Use of $\widehat{a}$ further stock protecting agent, namely epoxyethane (ethylene oxide), is no longer permitted.

New Stock Protecting Agents: A newly developed stock protecting agent, magnesium phosphide, which is about to replace aluminium phosphide, must be mentioned.

Aluminium phosphide [Phostoxin] is recommended in

21 countries (US, IT, KO, BR, ME, GR, TR, TH,

ZI, CA, PH, AR, BU, ID, FR, YU, CO, TN, DR, ZA, SA),

magnesium phosphide [Magtoxin] in 5 countries (US, $\mathrm{BR}, \mathrm{TH}, \mathrm{AR}, \mathrm{YU})$.

Another newly introduced stock protecting agent, for which a recommended maximum residue amount bas been fixed, is methoprene [Kabat], recommended in the United States and Thailand.

\section{Growth Regulating Agents}

This group of agents was not mentioned in the West German decree on maximum amounts for plant treat-

Table 10.

Growth regulation agents Introduced later than 1978.

\begin{tabular}{|c|c|}
\hline Growth regulation agents & recommended in \\
\hline pendimethalin [Accotab, Prowl] " & $\begin{array}{l}7 \text { countries } \\
\text { (US, IT, BR, GR, Zl **, } \\
\text { AR, SA) }\end{array}$ \\
\hline n-Decanol [Royaltac] & $\begin{array}{l}5 \text { countries } \\
\text { (US, IT, BR, ZI, CA) }\end{array}$ \\
\hline chlorpropham (cloro IPC) & $\begin{array}{l}2 \text { countries } \\
\text { (US, ZI"*) }\end{array}$ \\
\hline Fair-Tac & $\begin{array}{l}2 \text { countries } \\
(\mathrm{CA}, \mathrm{SA})\end{array}$ \\
\hline flumetralin [Prime +] & $\begin{array}{l}2 \text { countries } \\
\text { (US, } \mathrm{ZZ}^{* *} \text { ) }\end{array}$ \\
\hline
\end{tabular}

* With a recommended maximum amount for tobacco products.

** On a trial basis only. ment because they are unimportant for foodstuffs of vegetable origin. But in agreement with the Federal Health Office, the 1978 publication (2) states: “The use . of growth regulating agents for sucker control is allowed if the rules of good agricultural practice are observed in such a way that the residue levels in the final product do not exceed the recommended maximum amount".

Only one agent had a recommended maximum amount in 1978 and is still being recommended:

maleic hydrazide $[\mathrm{MH}]$ in 4 countries (US, IT, BR, AR).

The following sucker control agents are still being recommended:

Antak (fatty alcohols) in 9 countries (US, IT, BR, ME, ZI, CA, AR, FR, SA),

Off-Shoot-T (fatty alcohols) in 4 countries (US, BR, AR, SA),

butralin [Amex] in 1 country (FR).

Ethephon [Ethrel], the yellowing agent mentioned in 1978, would appear to be used only in the United States.

New Growth Regulating Agents: New growth regulating agents recommended since 1978 are compiled in Table 10.

\section{REFERENCES}

1. North Carolina Agricultural Extension Service: Extension-Research Tobacco Pathology Program: 1984 Summary Report; North Carolina State University, Raleigh, North Carolina, 1984.

2. Wittekindt, W.: Current West German regulations on maximum pesticide residues in tobacco products; Tobacco-Journal International 1978, No. 4, 222229.

3. North Carolina Agricultural Extension Service: 1984 Tobacco Information; North Carolina State University, Raleigh, North Carolina, 111 pp.

4. Wittekindt, W.: How to maintain tobacco quality in cases of treatment against insects, sucker growth and blue mold; Proc. 6th Int. Tob. Sci. Congr. (CORESTA), Tokyo, 1976, 171-172.

5. Wittekindt, W.: Residues of plant protecting agents - Necessities and limits of residue methods; presented at the 8th Int. Tob. Sci. Congr. (COREsTa), Vienna, 1984, CORESTA Information Bulletin 1984, Special Issue, 131-132.

6. a) Akehurst, B. C.: Tobacco; Longman Group Limited, London and New York, 2nd edition, 1981.

b) Lucas, G. B.: Diseases of tobacco; Biological Consulting Associates, Raleigh, North Carolina, 3rd edition, 1975. 
c) Todd, F. A.: Flue-cured tobacco - Producing a healthy crop; Tobacco Consultants, Inc., Wendell, North Carolina, 1st edition, 1981.

7. a) Farm Chemicals Handbook 1984; Meister Publishing Co., Willoughby, Ohio, 1984.

b) Nanogen Index - A dictionary of pesticides and chemical pollutants, edited by Kingsley Packer; Nanogens International, Freedom, Calif., 1975.

8. a) Elliott, M.: Properties and applications of pyrethroids; Environ. Health Perspect. 14 (1976) 3-13.

b) Rajakulendran, S. V., and F. W. Plapp, Jr.: Comparative toxicities of five synthetic pyrethroids to the tobacco budworm (Lepidoptera: Noctuidae), an ichneumonid parasite, Campoletis sonorensis, and a predator, Cbrysopa carnea; J. Econ. Entomol, 75 (1982) 769-772. c) Wettstein, K.: Some interesting biological properties of Cybolt flucythrinate; Mededelingen Fakulteit van de Landbouwwetenschappen (Rijksuniversiteit Gent) 48/2 (1983) 331-339.

Author's address:

Verband der Cigarettenindustrie, Wissenschaftiche Abteilung,

Harvestehuder Weg 88,

D-2000 Hamburg 13. 